\title{
Performance assessment in IFLA and United Kingdom academic libraries
}

\author{
John Willemse \\ Unisa Library, P.O. Box 392, Pretoria, 0003 Republic of South Africa \\ willej@alpha.unisa.ac.za
}

\begin{abstract}
The IFLA Section of University Libraries and other General Research Libraries has, after giving attention to performance measurement over many years, produced a set of international guidelines which were published in 1996. A survey, based on a similar one done in the United Kingdom, was undertaken to establish to what extent the members of the section were committed to applying performance measurement in their libraries. The results of the IFLA study are analysed and compared with those of the UK one.
\end{abstract}

Die IFLA Seksie vir Universiteitsbiblioteke en ander Algemene Navorsingsbiblioteke het, nadat oor baie jare besondere aandag aan prestasiemeting bestee is, gedurende 1996 'n stel riglyne vir prestasiemeting gepubliseer. 'n Opname, gebaseer op 'n soortgelyke studie in die Verenigde Koninkryk, is onderneem om te bepaal tot watter mate die lede van die seksie prestasiemeting in hul biblioteke in die praktyk toegepas het. Die resultate van die IFLA studie word ontleed en met dié van die Verenigde Koninkryk-studie vergelyk.

During the 1988 IFLA conference in Sydney the need for evaluation of academic library services by way of performance assessment was considered for the first time by its Section of University Libraries and other General Research Libraries (Willemse 1989). It was argued that libraries need to convince their funding authorities of the relevance of their goals and to show their effectiveness to obtain the required financial support for their services. To realise these goals, concrete objectives which have to reflect the needs of the different user groups, must be formulated and the library's performance in respect of these objectives must be determined. The problem experienced by libraries in formulating concrete goals and objective performance measures was discussed against the background of the literature on organisational effectiveness.

This was followed by a workshop during the 1989 conference in Paris, where participants by way of a nominal group technique session agreed on the following as the most appropriate performance measures (Willemse 1990 ):

- relevance in collection development

- degree of satisfaction

- hours open

- delay between order and availability on shelves

- percentage of requested items obtained.

At the Stockholm conference (1990) the workshop was followed by an open session on performance measures after which the IFLA section decided to establish a working group to formulate guidelines on performance measurement based on inter alia the following criteria (Poll 1996:7-8):

'to take care that the indicators should be applicable to all types of academic libraries, whether big or small, automated or not, with free access or closed stacks to measure effectiveness, not efficiency (costeffectiveness) to concentrate on user-orientated indicators'.

The working group could only hope to realise these goals by concentrating on a limited number of indicators and by stressing that they must be easy to use. After evaluating the existing literature on performance measurement, about 30 indicators were chosen, which were later narrowed down to 17. All indicators were tested by either the libraries or members of the working group or with the help of other libraries, in order to analyse problems and see whether alternative methods for an indicator could be found.

The first results were shown at a poster session at the Moscow conference (1991) which generated considerable interest. The next results were shown at a workshop at the New Delhi conference (1992), and the first draft of guidelines was presented at the Barcelona conference (1993). The working group received numerous comments and suggestions, due also to a discussion group on performance measurement established by the IFLA section. These comments and results of further tests were incorporated in the guidelines, as was the experience of two members of the group who joined the new ISO group (TC46/SC8/WG4) on an international standard on performance indicators for libraries.

The guidelines were eventually published in 1996 under the title Measuring quality: international guidelines for performance measurement in academic libraries, by K.G. Saur (Poll 1996). At that stage it seemed appropriate to determine to what extent the members of the IFLA section were applying performance measurement in their libraries. A survey of members of the section was proposed, based on a similar study done by Morgan (1993) in the United Kingdom.

\section{Objectives of the survey}

Morgan indicated that the Library Association has 'guidelines for academic library managers so that the institutions may fulfil their role of setting relevant, demanding objectives and providing adequate resources of staff, money and space. Although well intentioned, these guidelines can only provide a brief 
resumé of the performance assessment criteria' (Morgan 1993:36).

It is therefore regarded as essential that mechanisms should be in place to monitor and evaluate the quality of the various aspects of a library's services.

The specific objectives of his survey were formulated to find out:

- 'How committed higher education institutions were to the assessment of their library services.

- How committed the libraries themselves were to the assessment of their performance.

- The extent of reader services evaluation, the methods used and the groups consulted.

- Which groups received the results of any evaluation process over the previous year.

- Satisfaction levels of library managers with current assessment procedures, where they existed, and how these might be improved'.

The objectives of the IFLA survey were essentially the same, although some changes in the questionnaire put some limitations on the comparability of the results of the two studies. The overriding purpose was however to assess to what extent performance assessment is at present being done in the libraries of the members of the IFLA Section of University Libraries and other General Research Libraries.

\section{Methodology}

A questionnaire survey was used, based on the questionnaire used in the UK study.

It was tested on the 20 members of the Standing Committee of the section after which a number of further changes were made. The questionnaire was divided into the following parts with questions on:

- existence of a written performance assessment policy;

- assessment of various library services;

- dissemination of performance assessment results; and

- satisfaction level with current assessment procedures.

A set of printed address labels and a list of all 401 members of the section were obtained from IFLA Headquarters at the end of 1996. After two months a second mailing was sent out to those institutions which had not reacted.

\section{Response rate}

Of the 401 members, representing libraries from all parts of the world, $75 \%$ did not react at all. Of the 101 that reacted, 14 replied that they had not received the questionnaire; unfortunately at such a late stage that it was impossible to include them. A further ten respondents indicated that their institutions were not academic libraries (for example the Danish. National Library Authority). Only 77 usable questionnaires were received, which for the reduced membership group of 377 (401 - 10 not libraries - 14 did not received questionnaire) provides a response rate of $20.4 \%$. This compares rather poorly with the $66 \%$ usable responses of the earlier UK study. The results of this study have therefore to be treated with some caution.

\section{Comparative results}

The summary results of the IFLA survey (Retief) are discussed and compared with the corresponding outcome of the UK study. It should be noted that the IFLA respondents represent mostly university libraries. The UK study on the other hand included 50 'old' universities, 40 'new' universities (polytechnics) and 29 colleges of higher education, although no figures are provided on the response received from these different groups.

\section{Commitment of parent institutions}

In order to determine the parent institution's commitment, libraries were asked about the existence of a written performance assessment policy for their institution. Only $29 \%$ of IFLA respondents indicated the existence of such a policy. Of these policies, $22 \%$ were included in the institution's mission statement or similar documents, whilst $78 \%$ of the respondents indicated that they were included in some other form of institutional documentation.

It is rather surprising to note that according to the respondents $71 \%$ of their institutions do not have a written performance assessment policy. In the UK study, which was done five years before the IFLA survey, 36\% indicated that their institutions had such a policy, leaving $64 \%$ which had not. Of the UK institutions that had policies, $25 \%$ were included in their mission statements. Despite the difference in time and the widely diverging populations, the results of the two studies are fairly similar.

Morgan mentions that it appeared from the comments that the development of a policy on performance assessment in many organisations was being addressed at an institutional level.

\section{Commitment of libraries}

On the question about the existence of a written assessment policy for the library, again 29\% of IFLA respondents answered yes, though it was not the same $29 \%$ as those who have a written policy for the institution. Of these two groups, only 15 or one third are the same and have a policy for both the institution and the library. The surprisingly high number (71\%) without a policy in most cases gave either the fact that the parent body or another outside organisation regulated the assessment of performance, or that they were in the process of developing a policy, or the lack of time to give attention to this as the reason for not having one.

Of those with a policy $30 \%$ have it in one discrete document, $57 \%$ have it covered in a range of library policies on different topics and $13 \%$ indicated that they have it in a discrete document as well as in a range of library policies.

The UK results were again very similar, with $30.8 \%$ having a policy and $69.2 \%$ not. Of those with a policy $71 \%$ indicated that is was covered in a range of policies rather than in one 
discrete document. Of the 54 libraries without a policy, 13 indicated that it was currently being developed, seven that they had insufficient time or staff to devote to assessment, while three polytechnics indicated that such policies were unnecessary since it was implicit in everything they did.

\section{Evaluation of services}

An important objective of the study was to find out to what extent services to library clients were being evaluated. Three service areas were specifically considered in line with the UK study, namely document delivery, the client enquiry and advice service and user education.

\section{Document delivery service}

This part of the IFLA study differs from the UK one, as it focusses on the applicable performance indicators in the IFLA guidelines. Respondents were asked to indicate which of these 16 indicators had been evaluated during the last 12 months, either regularly, irregularly or not at all. Table 1 presents the list in the order of those being evaluated most frequently (both regularly and irregularly) to those evaluated the least.

The order of frequency of the services evaluated regularly differs considerably from those evaluated irregularly and accordingly as well from the order of frequency of the totals as given above:

Table 1 Performance assessment of document delivery services

\begin{tabular}{lcc}
\hline & $\begin{array}{c}\text { Percent } \\
\text { evaluation }\end{array}$ & $\begin{array}{c}\text { Percent non } \\
\text { evaluation }\end{array}$ \\
\hline User satisfaction & 72 & 28 \\
Interlibrary loan speed & 69 & 31 \\
Opening hours compared to demand & 67 & 33 \\
Document delivery time & 66 & 34 \\
Book processing speed & 59 & 41 \\
Acquisition speed & 57 & 43 \\
Subject collection use & 53 & 47 \\
Availability & 48 & 52 \\
Subject search & 45 & 55 \\
Documents not used & 35 & 65 \\
Known-item-search & 33 & 67 \\
Market penetration & 31 & 69 \\
User satisfaction (remote users) & 31 & 69 \\
Expert checklists & 30 & 70 \\
Remote users per capita & 30 & 70 \\
Correct answer fill rate & 28 & 72 \\
\hline
\end{tabular}

\section{Evaluated regularly}

Interlibrary loan speed

$29 \%$

Document delivery time

$27 \%$

$27 \%$

$24 \%$

$24 \%$

$24 \%$

User satisfaction was evaluated regularly by only $16 \%$ of the respondents, though it had by far the highest score with $56 \%$ done on an irregular basis. If one considers that this form of assessment is often done on a project basis, which does not lend itself easily to regular evaluation, the result is not surprising.

\section{Evaluated irregularly}

$\begin{array}{ll}\text { User satisfaction } & 56 \% \\ \text { Collection use } & 47 \% \\ \text { Document delivery } & 39 \% \\ \text { Subject collection use } & 37 \% \\ \text { Book processing speed } & 35 \% \\ \text { Acquisition speed } & 33 \%\end{array}$

The relatively low score of $24 \%$ for availability, which also determines its position in the middle of the list of total scores, is lower than could be expected in view of the fact that this can be considered one of the key measures for success of any library. It is also the measure which has been best developed and probably has been most written about of any performance measure.

As the UK study only looked at the evaluation of book collections (done by $50 \%$ ), periodical collections $(51.3 \%$ ), interlibrary loans service $(32.1 \%)$ and reservation service $(26.9 \%)$, it is almost impossible to make a meaningful comparison. Although the questions asked were not the same and the results therefore are in many respects not comparable, the most obvious difference is the low score of $32.1 \%$ for interlibrary loans evaluation (including speed) in the UK, compared to $69 \%$ for the evaluation of speed only in the IFLA study.

Looking at the overall picture for document delivery services, IFLA respondents evaluated the various indicators on the list as follows:

$\begin{array}{ll}\text { Yes, regularly } & \text { between } 29 \%-4 \% \\ \text { Yes, irregularly } & \text { between } 56 \%-19 \% \\ \text { Yes, total } & \text { between } 72 \%-28 \%\end{array}$

In the UK, $69.2 \%$ of respondents did some form of assessment and $30.8 \%$ did no assessment at all.

Apart from the above-mentioned reasons for not having a policy, a number of IFLA respondents indicated that it was not required or that they did not feel the need for any evaluation.

\section{Clients' enquiry and advice service}

According to the IFLA results, $41 \%$ of the respondents indicated that their library's enquiry service had been evaluated during the past 12 months. This is significantly higher than the UK findings of $24.4 \%$. This means that just under 
$60 \%$ of IFLA libraries and three-quarter of the UK libraries did not evaluate their enquiry service at all.

IFLA respondents used a wide variety of evaluation methods:

$\begin{array}{ll}\text { Interview } & 32 \% \\ \text { Course board/committee } & 21 \% \\ \text { Survey } & 72 \% \\ \text { Observation } & 48 \% \\ \text { Other } & 18 \%\end{array}$

In the UK a similar $73.7 \%$ used surveys, but the only other method mentioned was observation. This may however have been the result of the way in which the question was formulated.

Groups consulted in the evaluation process were in both cases predominantly students (IFLA 71\%/UK 73.7\%), academic staff $(68 \% / 73.7 \%)$ and library staff (59\%/47.4\%), whilst IFLA respondents mentioned $18 \%$ other groups. These others include surrogate/proxy users, external users, corporate users, colleagues and users from other libraries or organisations, researchers and community clients. In the UK study other groups consulted were course boards and library committees.

Again more or less the same reasons as before were given by those that did not evaluate this service, for example insufficient time or staff or low priority. In the UK the difficulty of assessing quality and the fact that they had not been asked to do such evaluation were mentioned more than once. IFLA respondents mentioned the fact that they had never thought about it and that it was very difficult and time consuming.

\section{User education services}

Asked if the performance of user education, including orientation and bibliographical instruction had been evaluated during the last twelve months, $52 \%$ of respondents said that they had done so. In the UK just under half $(46.2 \%)$ of the libraries indicated that they had assessed these programmes.

Evaluation methods used by IFLA respondents were more or less similar to those used to evaluate the enquiry service:

$\begin{array}{ll}\text { Interview } & 23 \% \\ \text { Course boards/committee } & 18 \% \\ \text { Survey } & 58 \% \\ \text { Observation } & 38 \% \\ \text { Other } & 15 \%\end{array}$

The last category includes spontaneous comments, letters, e-mail from academic staff, user education database for indepth analysis of activities and review by young members of library staff.

UK libraries only mentioned surveys (25 libraries), observation (13) and interviews (9).

In both cases the groups consulted were students, library staff and academic staff. In the IFLA study reference was made to all users of the library and in the UK course boards were mentioned by nine libraries.

Reasons for non-assessment were again similar to those mentioned before, though it should be mentioned that many of the respondents in both studies seem to regard the evaluation of user education services as unimportant and of low priority.

\section{Other services}

It is interesting to note that one third of the IFLA respondents and half of the UK respondents mentioned a number of other services which they had evaluated during the last 12 months. These were for the greater part services of a more specific nature, for example short loan, audio-visual or branch collections, photocopying services and reference and archival collections.

\section{Dissemination of performance assessment results}

In the IFLA study $52 \%$ of respondents indicated that they disseminated the results of the library performance assessment outside the library and in the UK $57.7 \%$ of respondents did so. In the UK the library committee was mentioned most, whereas management or governors were most often mentioned by the IFLA respondents. An analysis of the UK responses shows that the polytechnic subgroup also reported mostly to institutional management. Academic staff and course boards were often mentioned, and students somewhat less. The IFLA group also disseminated the results to other libraries.

It is understandable that libraries in some instances would want to do the assessment for internal library management purposes. Unless the results indicate poor performance, much could be gained from making the results widely known. This is particularly true if the library needs to convince its funding body about its relevance, as is argued at the beginning of this article.

\section{Satisfaction with current procedures}

IFLA respondents were mostly less than reasonably satisfied to dissatisfied (47\%), with $37 \%$ reasonably and $16 \%$ more than reasonably to satisfied. The UK figures indicate an average satisfaction of $40.8 \%$.

Improvements in the way performance assessment could be done that were suggested by IFLA respondents include training of staff in assessment procedures, standardising and simplifying assessment procedures, developing bench marks, establishing a written policy and implementing it, more regularity and by having a single performance assessment document that links performance and achievement with the mission and corporate goals of the library.

\section{Conclusion}

Both studies endeavoured to establish to what extent parent institutions were committed to performance assessment on the basis of existing policies in this regard.

The results of the IFLA survey indicate that at the time when the guidelines for performance measurement were published, less then a third of the parent institutions had a written policy, in spite of the fact that funding authorities in many parts of the world require assessment of one kind or 
another. The UK study, done almost five years earlier, found that a little over a third had such policies. In both cases indications were that a considerable number of institutions were in the process of giving attention to the development of a policy. The findings certainly do not indicate that because two thirds of the institutions do not have a written policy, these institutions do not regard performance assessment as unimportant.

As far as the commitment of the libraries themselves is concerned, it was found that less than a third of both the IFLA and UK respondents had a written policy. From the rest of the survey it is clear that many of those without a policy do however evaluate at least some parts of their services.

In respect of user or document delivery services the 16 applicable IFLA performance indicators were used by a quarter to a three-quarter of the IFLA respondents to assess their performance at least once. Only a quarter or less of the respondents were using a few of these indicators to evaluate their services on a regular basis.

Although the UK study was done on a different basis the results indicate that, just like IFLA, close to a quarter of respondents did not do any evaluation of these services at all.

Assessment of clients' enquiry and advice services showed a greater variance than in other aspects. About $60 \%$ of IFLA respondents and a three-quarter in the UK did not evaluate the enquiry service. User education again was not assessed by just under half of the IFLA group and just over half of the UK group.
In both studies over half of the respondents disseminated the assessment results outside the library, leaving a substantial number that did not do so. This seems a matter which should receive further attention. In fact Cullen (1998:3-20) has asked some very important questions about the contribution of performance measurement to organisational effectiveness, which should receive serious attention by all interested in this subject.

\section{References}

Cullen, R. 1998. Does performance measurement improve organisational effectiveness? A post-modern analysis. In Proceedings of the 2nd Northumbria International Conference on Performance Measurement in Libraries and Information Services ... September 1997. Newcastle-upon-Tyne.

Morgan, S. 1993. Performance assessement in higher education libraries. Library management, 14(5):35-42.

Poll, R., Te Boekhorst, P. et al. 1996. Measuring quality: international guideliness for performance measurement in academic libraries. Munchen: K.G. Saur. (IFLA Publications 76).

Retief, E. 1997. Performance assessment in academic libraries: Jan \& June 1997. Pretoria, Unisa Library. (Unpublished).

Willemse, J. 1989. Library effectiveness - the need for measurement. South African journal of library and information science, 57(3):261-266.

Willemse, J. 1990. Summary of the Paris workshop 1989 on performance measurement. IFLA journal, 16(4):458-462. 